\title{
The Relation between Microvascular Complications of Type II Diabetes with Levels of Serum Progranulin.
}

\author{
Rania El-Sayed Sheir ${ }^{a}$, Mohamed Nabil salem ${ }^{a}$, Rehab Muhammad AbdelKarem ${ }^{b}$ and \\ Mohamed Ahmed Mamdouh ${ }^{a}$ \\ ${ }^{a}$ General internal medicine department, faculty of medicine, Beni-suef university, Egypt. \\ b clinical and chemical pathology department, Faculty of Medicine, Beni-Suef University, \\ Egypt.
}

\begin{abstract}
This study elucidated for the first time that serum PGRN concentrations increased in Egyptian patients during presence of several microvascular complications. PGRN is considered as a biomarker for diabetic microangiopathy and its severity and it is serum level was increased due to close relation with progress of diabetic microangiopathy. It is subsequently proved that PGRN level in diabetic patients suffered from type II diabetes should be owing high solicitude for diagnosis and following up. These results fundamentals that PGRN level could be used as a potential therapeutic target for management.
\end{abstract}

Keywords: PGRN, Microangiopathy.

\section{1-Introduction}

Diabetes mellitus type II shown several devastating dysfunctions that results from combination of resistance to insulin action, inadequate insulin secretion and excessive or in appropriate glucagon secretion [1]. Microvascular, macrovascular complications are more prevalent in poorly controlled type II diabetic patients [2]. The pathogenesis of microvascular complications has considerable attention in recent years where studies shown that inflammatory process appeared to be a major mechanism that responsible for microvascular damage in type II diabetes [3]. For example, Activation of growth factors and adhesion molecules leads to movement of inflammatory cells to the renal microvasculature, which act as a predisposing factor of diabetic nephropathy [4]. Progranulin (PGRN) is known as proepithelin, acrogranin, PC cell derived growth factor, and granulin-epithelin precursor with a 68-88 Kilo Dalton (kDa) protein [5]. PGRN is present in adipose tissue, epithelial 
tissue, gastrointestinal tract, reproductive organs and involved in cell growth and survival as well as present during inflammatory response [6]. PGRN levels are elevated in patients with type II diabetes and constitute an important molecule of the inflammatory response, which in recent years appears to have a great role in microvascular complications process [7].

\section{2-Patients and Methods}

Adult Egyptian patients had been selected from clinic of Internal Medicine Department, Beni-Suef University Hospital. Informed consent was taken from patients before stating this study. Data had been collected, reviewed \& analyzed retrospectively from 80 persons, which divided into two groups: Group I, which included 60 patients with DM type II. Group II, which included 20 normal, volunteer persons as a control where age and sex were matched.

\section{Inclusion criteria}

Type II diabetic patients diagnosed more than five years ago according to American diabetic association criteria 2015 as followings:1-Fasting plasma glucose (FPG) $\geq 126 \mathrm{mg} / \mathrm{dL}(7.0 \mathrm{mmol} / \mathrm{L})$ where fasting is defined as no caloric intake for $\geq 8$ hours. 2Two hour's plasma glucose (2-hr PG) $\geq 200$ $\mathrm{mg} / \mathrm{dL}(11.1 \mathrm{mmol} / \mathrm{L})$ during oral glucose tolerance test (OGTT) through using of a glucose load containing equivalent of $75 \mathrm{~g}$ anhydrous glucose dissolved in water. 3Hemoglobin A1C $\geq 6.5 \%$ (48 $\mathrm{mmol} / \mathrm{l})$. 4Random plasma glucose $(\mathrm{PG}) \geq 200 \mathrm{mg} / \mathrm{dL}$ $(11.1 \mathrm{mmol} / \mathrm{L})$ that detected in individuals with symptoms of hyperglycemia.

Exclusion criteria, Patients had the following conditions were excluded from this study, 1-Past history of malignancy and degenerative diseases of nervous system. 2Other endocrine diseases, which affect glucose metabolism and lipid metabolism. 3Chronic hepatitis, primary kidney disease, pregnancy, and history of drug abuse.

\section{Statistical methodology}

Analysis of data was done by IBM computer using SPSS (statistical program for social science) as follows; description of quantitative variables as mean, SD and range. Description of qualitative variables as number and percentage. Unpaired t-test was used to compare quantitative variables, in parametric data $(\mathrm{SD}<50 \%$ mean $)$

- $\mathrm{P}$ value $>0.05$ insignificant

- $\mathrm{P}<0.05$ significant

- $\mathrm{P}<0.01$ highly significant [20].

\section{3-Results}

This study was conducted on 60 patients diagnosed to suffer from Type II diabetes mellitus according to American diabetic association (ADA). Patients were recruited from outpatient clinic of Internal Medicine Department of Beni-Suef University. Patients constituted from 28 males and 32 
females where their ages ranged from 23 to

76 years old with a mean age of 55 years old.

Table (12): Demographic parameters in patient group

\begin{tabular}{|c|c|c|c|c|c|}
\hline Patient & N & Minimum & Maximum & Mean & SD \\
\hline Age(Year) & 60 & 23 & 77 & 55.3 & 10.8 \\
\hline
\end{tabular}

Table (13): Demographic parameters in control group

\begin{tabular}{|l|l|l|l|l|l|}
\hline Control & N & Minimum & Maximum & Mean & SD \\
\hline Age(Year) & 20 & 23 & 76 & 42.1 & 15.9 \\
\hline
\end{tabular}

Table (14): Comparison between patient and control group as regarding demographic parameters:

\begin{tabular}{|l|l|l|l|l|l|l|}
\hline \multirow{3}{*}{ Variables } & \multicolumn{2}{|l|}{ Cases (n=60) } & \multicolumn{2}{|l|}{ Control (n=20) } & \multirow{2}{*}{ p-value } & \multirow{2}{*}{ Sig. } \\
\cline { 2 - 5 } & \multicolumn{7}{|l|}{} & \multicolumn{2}{|l|}{} \\
\cline { 2 - 5 } & No. & \% & No. & \% & \\
\hline Gender: & 28 & $46.7 \%$ & 5 & $25 \%$ & \multirow{2}{*}{0.1} & \multirow{2}{*}{ NS } \\
\hline Male & 32 & $53.3 \%$ & 15 & $75 \%$ & & \\
\hline Female & Mean & SD & Mean & SD & & NS \\
\hline Age (years) & 55.3 & 10.8 & 42.1 & 15.9 & 0.08 & \\
\hline
\end{tabular}

Table. 14 illustrates that there is no statistical significant difference with $p$-value $>0.05$ between cases and control as regards sex and age distribution which indicated proper matching between two study groups.

Table (15): Laboratory parameters in patient group

\begin{tabular}{|l|l|l|l|l|l|}
\hline Patient & N & Minimum & Maximum & Mean & SD \\
\hline HB & 60 & 7.2 & 15.8 & 11.3 & 1.6 \\
\hline & & & & & \\
\hline NA & 60 & 126 & 148 & 135.8 & 3.6 \\
\hline K & 60 & 2.7 & 6.1 & 4.1 & 0.7 \\
\hline Urea & 60 & 11 & 376 & 92.7 & 75.9 \\
\hline Creatinine & 60 & 0.7 & 12.1 & 3.3 & 3 \\
\hline HB A1c & 60 & 4.5 & 13.3 & 7 & 1.9 \\
\hline A/C Ratio & 60 & 15.8 & 3240 & 431.8 & 776.5 \\
\hline
\end{tabular}

Table (16): Laboratory parameter in control group

\begin{tabular}{|l|l|l|l|l|l|}
\hline cases & N & Minimum & Maximum & Mean & SD \\
\hline HB & 20 & 10 & 14 & 12.1 & 1.1 \\
\hline NA & 20 & 131 & 145 & 137.4 & 3.4 \\
\hline
\end{tabular}




\begin{tabular}{|l|l|l|l|l|l|}
\hline K & 20 & 3.1 & 5.5 & 3.9 & 0.45 \\
\hline Urea & 20 & 8 & 45 & 31.6 & 15.2 \\
\hline Creatinine & 20 & 0.8 & 1.2 & 1 & 0.27 \\
\hline HB A1c & 20 & 5 & 6.4 & 5.6 & 0.4 \\
\hline A/C Ratio & 20 & 20 & 29 & 24.9 & 2.8 \\
\hline
\end{tabular}

Table (17): Comparison between patient and control group as regarding laboratory parameters:

\begin{tabular}{|l|l|l|l|l|l|l|}
\hline \multirow{2}{*}{ Variables } & \multicolumn{2}{|l|}{ Cases $(\mathbf{n}=\mathbf{6 0})$} & \multicolumn{2}{l|}{ Control $(\mathbf{n}=\mathbf{2 0})$} & \multirow{2}{*}{ p-value } & \multirow{2}{*}{ Sig. } \\
\cline { 2 - 5 } & Mean & SD & \multicolumn{1}{|c|}{ Mean } & SD & & \\
\hline HB & 11.3 & 1.6 & 12.1 & 1.1 & 0.002 & S \\
\hline Hb A1c & 7 & 1.9 & 5.6 & 0.42 & 0.001 & HS \\
\hline Na & 135.8 & 3.6 & 137.4 & 3.4 & 0.09 & NS \\
\hline K & 4.1 & 0.67 & 3.9 & 0.45 & 0.48 & NS \\
\hline Urea & 92.7 & 75.9 & 31.6 & 15.2 & 0.001 & HS \\
\hline Creatinine & 3.29 & 3 & 1.1 & 0.27 & 0.001 & HS \\
\hline A/C ratio & 431.8 & 776.5 & 24.95 & 2.83 & 0.001 & HS \\
\hline
\end{tabular}

Table 17 illustrates that there is statistically significant difference with p-value $<0.05$ between cases and control as regards hemoglobin, HbAlc, urea, creatinine, with low mean of hemoglobin and high mean of, urea, creatinine, and $\mathrm{A} / \mathrm{C}$ ratio among diabetic patients. On the other hand, there is no statistically significant difference with p-value $>0.05$ between cases and control as regards sodium and potassium level.

Table (18): Comparisons of serum progranulin in patients under study

\begin{tabular}{|l|l|l|l|l|}
\hline \multirow{2}{*}{ Variables } & \multicolumn{2}{|l|}{ Serum Progranulin } & \multirow{2}{*}{ p-value } & \multirow{2}{*}{ Sig. } \\
\cline { 2 - 3 } & Mean & SD & & \\
\hline Cases (n=60) & 13.87 & 6.08 & \multirow{2}{*}{0.002} & S \\
\hline Control (n=20) & 8.7 & 5.8 & \\
\hline
\end{tabular}

Table illustrates that there is statistically significant difference with p-value $>0.05$ between cases and control as regards serum progranulin which indicated impact of diabetes on serum progranulin level.

Table (19): Comparisons of fundus examination in different studied groups

\begin{tabular}{|c|l|l|l|l|l|l|}
\hline \multirow{2}{*}{ Variables } & \multicolumn{2}{|l|}{ Cases $(\mathbf{n}=\mathbf{6 0})$} & \multicolumn{2}{l|}{ Control (n=20) } & \multirow{2}{*}{ p-value } & \multirow{2}{*}{ Sig. } \\
\cline { 2 - 5 } & No. & $\mathbf{\%}$ & No. & $\mathbf{\%}$ & & \\
\hline Fundus examination & 34 & $56.7 \%$ & 20 & $100 \%$ & \multirow{2}{*}{$<0.001$} & \multirow{2}{*}{ HS } \\
\hline Normal & 26 & $43.3 \%$ & 0 & $0 \%$ & & \\
\hline NPDR & 26 &
\end{tabular}


Table 19 illustrates that there is statistically significant difference with p-value $<0.05$ between cases and control as regards results of fundus with high percentage of Non- proliferative diabetic retinopathy (NPDR)

Table (20): Comparisons of neurological examinations in different studied groups

\begin{tabular}{|l|l|l|l|l|l|l|}
\hline \multirow{2}{*}{ Variables } & \multicolumn{2}{|l|}{ Cases (n=60) } & \multicolumn{2}{l|}{ Control (n=20) } & \multirow{2}{*}{ p-value } & \multirow{2}{*}{ Sig. } \\
\cline { 2 - 5 } & No. & \% & No. & $\mathbf{\%}$ & & \\
\hline Neurological examination & 38 & $63.3 \%$ & 0 & $0 \%$ & \multirow{2}{*}{$<0.001$} & \multirow{2}{*}{ HS } \\
\hline Yes & 22 & $36.7 \%$ & 20 & $100 \%$ & \\
\hline No & 22 &
\end{tabular}

Table illustrates that there is statistically significant difference with p-value $<0.05$ between cases and control as regards results of neurological examination with high percentage of positive peripheral neurological finding among cases of diabetes (In the form of negative vibration sense test and monofilament test).

Table (21): Comparisons of serum progranulin with fundus examination among patient group

\begin{tabular}{|l|l|l|l|l|}
\hline \multirow{2}{*}{ Variables } & \multicolumn{2}{|l|}{ Serum Progranulin } & \multirow{2}{*}{ p-value } & \multirow{2}{*}{ Sig. } \\
\cline { 2 - 3 } & Mean & SD & \multicolumn{2}{l|}{} \\
\hline Fundus examination & 14.3 & 5.05 & \multirow{2}{*}{0.04} & S \\
\hline Diabetic retinopathy: & 15.6 & 5.1 & & \\
\hline Non-Diabetic retinopathy &
\end{tabular}

Table illustrates that there is statistically significant difference with p-value $<0.05$ between cases and control as regards results of fundus examination and its relation to serum progranulin with high percentage of Non-proliferative diabetic retinopathy (NPDR)

Table (22): Comparisons of serum progranulin \& neurological examination among patient group

\begin{tabular}{|l|l|l|l|l|}
\hline \multirow{2}{*}{ Variables } & \multicolumn{2}{|l|}{ Serum Progranulin } & \multirow{2}{*}{ p-value } & \multirow{2}{*}{ Sig. } \\
\cline { 2 - 3 } & Mean & SD & \multicolumn{2}{|l|}{} \\
\hline Neurological examination & 15.1 & 6.5 & \multirow{2}{*}{0.04} & S \\
\hline Yes & 11.7 & 4.5 & & \\
\hline No &
\end{tabular}

Table illustrates that there is statistically significant difference with p-value $<0.05$ between cases and control as regards results of neurological examination and its relation to serum 
progranulin with high percentage of positive peripheral neurological finding among cases of diabetes (In the form of negative vibration sense test and monofilament test).

Table (23): Comparisons of different stages of proteinuria among diabetic cases in the study:

\begin{tabular}{|l|l|l|}
\hline \multirow{2}{*}{ Variables } & Cases $(\mathbf{n}=\mathbf{6 0})$ & \\
\cline { 2 - 3 } & No. & $\mathbf{\%}$ \\
\hline Normo-albuminuria & 13 & $21.6 \%$ \\
\hline Micro-albuminuria & 34 & $56.6 \%$ \\
\hline Macro-albuminuria & 13 & $21.6 \%$ \\
\hline
\end{tabular}

Table (24): Comparisons of stages of proteinuria among diabetic cases and its relation to serum progranulin level

\begin{tabular}{|l|l|l|l|l|l|l|}
\hline \multirow{2}{*}{ Variables } & \multicolumn{2}{|l|}{$\begin{array}{l}\text { A/C Ratio of } \\
\text { cases }\end{array}$} & $\begin{array}{l}\text { Serum } \\
\text { Progranulin }\end{array}$ & p-value & Sig. \\
\cline { 2 - 7 } & $\begin{array}{l}\text { Mea } \\
\text { n SD }\end{array}$ & Mean & SD & & \\
\hline $\begin{array}{l}\text { Normo- } \\
\text { albuminuria }\end{array}$ & 24.0 & 4.2 & 12.67 & 7.76 & 0.004 & S \\
\hline $\begin{array}{l}\text { Micro- } \\
\text { albuminuria }\end{array}$ & 114.3 & 112 & 14.25 & 4.73 & 0.001 & HS \\
\hline $\begin{array}{l}\text { Macro- } \\
\text { albuminuria }\end{array}$ & 1424 & 867.9 & 14.18 & 6.94 & 0.004 & S \\
\hline
\end{tabular}

Table illustrates that there is statistically significant difference with $\mathrm{p}$-value $<0.05$ between cases and control as regards results of labs indicating diabetic nephropathy in relation to serum progranulin level especially in case of microalbuminuria.

Table (25): Comparisons of serum progranulin in different gender among diabetic group.

\begin{tabular}{|c|l|l|l|l|}
\hline \multirow{2}{*}{ Sex } & \multicolumn{2}{|l|}{ Serum Progranulin } & \multirow{2}{*}{ p-value } & \multirow{2}{*}{ Sig. } \\
\cline { 2 - 3 } & Mean & SD & & \multirow{2}{*}{0.9} \\
\hline Male & 13.8 & 6.2 & \multirow{2}{*}{ NS } \\
\hline Female & 13.9 & 6.1 & & \\
\hline
\end{tabular}

Table illustrates that there is no statistically significant difference with p-value $>0.05$ between different gender as regards serum progranulin which indicated no impact of sex on serum progranulin level.

Table (29): Correlation between serum progranulin in studied diabetic group.

\begin{tabular}{|l|l|l|l|}
\hline \multirow{2}{*}{ Variables } & Serum Progranulin \\
\cline { 2 - 4 } & $\begin{array}{l}\text { Correlation coefficient } \\
\text { ® }\end{array}$ & p-value & Sig. \\
\hline Age (years) & 0.28 & 0.08 & NS \\
\hline HB & 0.19 & 0.1 & NS \\
\hline HbA1c & 0.036 & 0.7 & NS \\
\hline
\end{tabular}




\begin{tabular}{|l|l|l|l|}
\hline $\mathbf{N a}$ & -0.12 & 0.3 & NS \\
\hline $\mathbf{K}$ & 0.004 & 0.9 & NS \\
\hline Urea & -0.011 & 0.9 & NS \\
\hline Creatinine & -0.009 & 0.9 & NS \\
\hline A/C ratio & 0.02 & 0.9 & NS \\
\hline
\end{tabular}

Table (30): Sensitivity and specificity of serum progranulin in diagnosis of micro-vascular complications among type II DM patients.

\begin{tabular}{|l|l|l|}
\hline & Serum Progranulin \\
\cline { 2 - 3 } & Fundus affection & Neuropathic \\
\hline Sensitivity & 0.815 & 0.75 \\
\hline Specificity & 0.377 & 0.525 \\
\hline PPV & 0.40 & 0.612 \\
\hline NPV & 0.799 & 0.677 \\
\hline Cut off & 9.5 & 11.5 \\
\hline Accuracy & 0.53 & 0.638 \\
\hline AUC & 0.645 & 0.683 \\
\hline
\end{tabular}

Latter table illustrates that there is no statistically significant correlation with $\mathrm{p}$ value $>0.05$ between serum progranulin and any of other variables in the study among diabetic patients. Table illustrated Sensitivity and specificity test for serum progranulin in detection of microvascular complication with illustrates probability of being true positive is $(53 \%)$ more than being false positive when repeat test 100 times with sensitivity $(81.5 \%)$ and specificity (37.7\%). Sensitivity and specificity test for serum progranulin in detection of neurological complication with illustrates probability of being true positive is $(63.8 \%)$ more than being false positive when repeat test 100 times with sensitivity $(75 \%)$ and specificity $(52.5 \%)$.

\section{Discussion}

Diabetes mellitus type II shown several devastating dysfunctions. According to [1] diabetes is a complex, chronic illness affects both genders all over the world and require continuous medical care with multifactorial risk reduction strategies beyond glycemic control $[8]$.

Ultimate clinical manifestations of diabetes mellitus encompass a number of pathologic changes involved small and large blood vessels, cranial and peripheral nerves, and skin as well as eye lenses [2]. These damages drive to hypertension, end stage chronic kidney disease, blindness, autonomic and peripheral neuropathy, amputations of lower extremities, myocardial infarction and cerebrovascular accidents [4]. Long term complications of diabetes still cause significant morbidity and mortality. The major causes of death in diabetic patients were recorded as complications from end stage chronic kidney disease whereas macrovascular diseases in patients have type II diabetes. Surplus mortality reason in 
diabetes is due to large blood vessel disease, predominantly myocardial infarction and stroke [9].

Progranulin (PGRN) was recently introduced during this decade as a novel marker of chronic inflammatory response in obesity and type 2 diabetes capable of directly affecting insulin signaling pathway and might be considered as a marker for diabetic microangiopathy and its severity [10]. PGRN is a multifunctional protein, which has been implicated in cell growth, wound repair, tumorigenesis, neurodevelopment, neuro-degeneration, and inflammation. Studies in this decade have shown that inflammation is a key process in occurrence of diabetes mellitus as well as all its disorders [10]. All latter situations grasped our attention to PGRN as an indicator and /or marker as well as a kind of adipocytokines with important functions in modulation of inflammatory events. So, this study predicts that PGRN detection in sera of Egyptian patients or predisposed persons from both genders will give a great valuable chance in detection, confirmation or both for diabetic patients especially type II DM. This study was conducted upon 60 patients diagnosed to suffer from Type II diabetes mellitus according to [1], Patients were recruited from outpatient clinic of Internal Medicine Department of Beni-Suef University. Patients constituted from 28 males and 32 females where their ages ranged between 23 to 76 years old with a mean age of $\mathbf{5 5}$ years old. Results illustrates that there is no statistical significant difference with $p$-value $>0.05$ between cases and control as regards sex and age distribution which indicated proper matching between two study groups as well as serum progranulin levels showed no significant difference between men and women that suggests that serum level of progranulin is not gender-dependent. These results agreed with those retrieved by Boulton et al. [11]. Results illustrates that there is statistically significant difference with p-value $<0.05$ between diabetic cases and control as regards hemoglobin, $\mathrm{HbAlc}$, sodium, potassium, urea, creatinine, and $\mathrm{A} / \mathrm{C}$ ratio. Results illustrates that there is statistically significant difference with $p$ value $>0.05$ between cases and control as regards serum progranulin which indicated impact of diabetes microangiopathy on serum progranulin level. Progranulin has been used as a chronic inflammation marker and seems to be a reason for renal damage, decreasing glomeruli filtration rate and increasing albuminuria and this explain the high level and significant difference of PGRN with urea, creatinine, and $\mathrm{A} / \mathrm{C}$ ratio in diabetic cases. On the other hand, there is no statistically significant difference with $p$ value $>0.05$ between cases and control as regards sodium and potassium level. Same results also reported by, Bruna and Luis [12]. Serum progranulin levels can be 
considered for management of type 2 diabetes mellitus and further studies are necessary to explain the effect of progranulin on the pathogenesis of metabolic risk factors. These suggestions were in harmony with results shown by other researchers [13]. Results illustrates that there is statistically significant difference with $\mathrm{p}$-value $<0.05$ between cases and control as regards results of fundus examination with high percentage of Non- proliferative diabetic retinopathy(NPDR), which indicate that serum progranulin is associated more strongly with microangiopathies rather than diabetic patients where microvascular complications didn't emerge yet. Results illustrates that there is statistically significant difference with $p$-value $<0.05$ between cases and control as regards results of neurological examination with positive peripheral neurological finding among cases of diabetes (In the form of negative vibration sense test and monofilament test) which indicate that serum progranulin is associated more strongly with microangiopathies rather than diabetic patients where microvascular complications didn't emerge yet. Results illustrates that made comparisons of serum progranulin in fundus examination among diabetic group and illustrates that there is statistically significant difference with pvalue $>0.05$ between different fundus examination results as regards serum progranulin which indicated correlation between fundus changes and serum progranulin level. These suggestions were in harmony with results shown by other researchers [14]. Results illustrates that there is statistically significant difference with pvalue $<0.05$ between different neurological examination results with high mean among patients with positive neurological examination., These suggestions were in harmony with results shown by other researchers [10]. Results illustrates that there is statistically significant difference with p-value $<0.05$ between cases and control as regards results of labs indicating diabetic nephropathy in relation to serum progranulin. These suggestions were in harmony with results shown by other researchers as [15]. Results illustrates that the percentage of patient under the study who has diabetic nephropathy with normoalbuminuria, micro-albuminuria, and macroalbuminuria or what is called overt proteinuria with $21.6 \%$ for both of normo and macro-albuminuria and $56.6 \%$ for micro-albuminuria. Results illustrates that there is statistically significant difference with $p$-value $<0.05$ between different stages of proteinuria using $\mathrm{A} / \mathrm{C}$ Ratio indicating diabetic nephropathy in relation to serum progranulin. Results illustrates that there is no statistically significant difference with $\mathrm{p}$ value $>0.05$ between different gender as regards serum progranulin which indicated no impact of sex on serum progranulin level. 
These suggestions were in harmony with results shown by other researchers [16]. Results illustrates that the sensitivity and specificity test for serum progranulin in detection of microvascular complication with illustrates probability of being true positive is $(53 \%)$ more than being false positive when repeat test 100 times with sensitivity $(81.5 \%)$ and specificity (37.7\%). Sensitivity and specificity test for serum progranulin in detection of neurological complication with illustrates probability of being true positive is $(63.8 \%)$ more than being false positive when repeat test 100 times with sensitivity $(75 \%)$ and specificity (52.5\%). This observation seems to suggest that PGRN is associated with diabetic microangiopathy and may be involved in the pathogenesis of diabetic microangiopathy. To clarify the relationship between the increased PGRN and the development of diabetic microvascular complications. Furthermore, serum PGRN levels had remarkable positive correlations with inflammatory process and may be considered as a biomarker for chronic inflammatory response in diabetic microangiopathy. The interactions between progranulin and inflammation were reported to be more complicated in some different reports and physiological function of PGRN is complex as demonstrated in Baker et al. [17]. During the inflammatory process, progranulin is digested into smaller peptides, called granulins, which are proinflammatory and neutralize the anti-inflammatory effect of intact progranulin. However, not all the actions of progranulin on inflammatory cells are proinflammatory. Recently progranulin is a ligand of TNFR and the anti-inflammatory effects of progranulin are mainly mediated by inhibition of TNF- $\alpha \alpha$-activated intracellular signaling. These results conformities with those obtained by Tang et al. [18]. Whereby, accurate mechanisms underlying the increase of progranulin in patients suffered from diabetic microangiopathy need further investigations. Since both cellular source of serum progranulin and its mechanisms of secretion are multiple it is unclear whether remarkable elevation of serum progranulin levels in patients with diabetic microangiopathy reflects a higher production or a reduced clearance as reported by $\mathbf{X u}$ et al. [10]. In accordance with results of this study, the most recent study reported that progranulin serum levels increased with renal damage, decreasing glomeruli filtration rate and increasing albuminuria, deteriorating renal function, and the renal elimination was a major route for circulation PGRN and therefore, reduced renal elimination may be one of the reasons for elevated circulating progranulin in end-stage diabetic nephropathy. Whereas differences in a few genes have been entangled in diabetic nephropathy causes and prime distinction in 
personage risk stay unexplained. Results also found by $\mathbf{X u}$ et al. [10] which is not in line with our study which reveals that there.

\section{This research faced a few limitations as}

followings: $\mathbf{1}^{\text {st }}$ limit is the economic coast of diagnostic kit because importation of this kit type had been done on my expense without support from any organization. $\mathbf{2}^{\text {nd }}$ limit is the number of collected samples from diabetic and predisposed patients were 60 and 20 from control group and this were small. So, non-significant associations between PGRN and some factors may become statistically remarkable if larger samples were studied. $3^{\text {rd }}$ limit is a crosssectional nature and does not clarify the causal relationship between serum progranulin levels and presence of diabetic microangiopathy. $4^{\text {th }}$ limit is the longitudinal observation of increased progranulin is required in subjects intervened by beneficent of different kidney functions.

\section{5- Conclusion:}

1- This study showing for the first time that serum PGRN concentrations increased in Egyptian patients during presence of several microvascular complications.

2- This study constructs that PGRN is considered as a biomarker for diabetic microangiopathy and its severity as well as it is serum level was increased due to close relation with the progress of diabetic microangiopathy.
3- This study subsequently proved that PGRN level in diabetic patients suffered from type 2 diabetes should be used for following up of microvascular complications but not for making diagnosis of DM type II.

4- This study fundamentals that PGRN level could be a potential therapeutic target for prevent or delay the emergence of microvascular complications especially retinopathy, neuropathy and nephropathy

\section{6- References}

1. American Diabetes Association, 2016. Diabetes Care; 39 (suppl. 1): S1-S106. Anakwe OO and Gerton GL. Acrosome biogenesis begins during meiosis: evidence from the synthesis and distribution of an acrosomal glycoprotein, acrogranin, during guinea pig spermatogenesis. Biol Reprod., 1990; 42:317-328.

2. Grant RW and Kirkman MS. Trends in the evidence level for the American Diabetes Association's "Standards of Medical Care in Diabetes" from 2005 to 2014. Diabetes care, 2015; 38:6-8.

3. Parchman ML, Zeber JE, Romero RR and Pugh JA. Risk of coronary artery disease in type 2 diabetes and the delivery of care consistent with the chronic care model in primary care settings: a STARNet study. Med Care, 2007; 45:1129-1134. 
4. Chow F, Ozols E, Nikolic-Paterson DJ, Atkins RC and Tesch GH. "Macrophages in mouse type 2 diabetic nephropathy: correlation with diabetic state and progressive renal injury," Kidney International, vol. 65 , no. 1 , pp. 116-128, 2004. References 77

5. Liu $\mathrm{C}$ and Bosch $\mathrm{X}$. "Progranulin: $\mathrm{a}$ growth factor, a novel TNFR ligand and a drug target," Pharmacology and Therapeutics, 2012; 133(1): 124-132.

6. Ong $\mathrm{C}$ and Bateman A. "Progranulin (granulin-epithelin precursor, PC-cell derived growth factor, acrogranin) in proliferation and tumorigenesis," Histology and Histopathology, 2003; 18(4): $1275-1288$.

7. Matsubara T, Mita A and Minami K. "PGRN is a key adipokine mediating high fat diet-induced insulin resistance and obesity through IL-6 in adipose tissue," Cell Metabolism, 2012; 15(1): 38-50.

8. Kaufman FR and Alexandria Ed. American Diabetes Association, 2012.

9. Bergmann K and Sypniewska G. Diabetes as a complication of adipose tissue dysfunction. Clin Chem Lab Med., 2013; 51:177-85.

10. Xu L, Zhou B, Li H, Liu J, Du J, Zang W, $\mathrm{Wu} \mathrm{S}$ and Sun H. Serum Levels of Progranulin are Closely Associated with Microvascular Complication in Type 2 Diabetes. Hindawi Publishing Corporation,
Disease Markers, 2015; Volume, Article ID 357279, 9 pages.

11. Boulton AJ, Vinik AI and Arezzo JC. Diabetic neuropathies: a statement by the American Diabetes Association. Diabetes Care, 2005; 28:956.

12. Bruna $\mathrm{BN}$ and Luis $\mathrm{HC}$. The role of progranulin in diabetes and kidney disease. Diabetology \& Metabolic Syndrome, 2015; 7:117

13. Shafaei A, Marjani A and Khoshnia A. Serum Progranulin Levels in Type 2 Diabetic Patients with Metabolic Syndrome. Doi: 10.1515/rjim-2016-0034 Rom. J. Intern. Med., 0, 0, 1-11.

14. Tuttle KR, Bakris GL and Bilous RW. Diabetic kidney disease: a report from an ADA Consensus Conference. Diabetes Care, 2014; 37: 2864-2883.

15. Institute of Diabetes and Digestive and Kidney Diseases (NIDDK). Am J Kidney Dis., 2003;42: 617-622

16. Patel A, MacMahon S and Chalmers J. ADVANCE Collaborative Group. Intensive blood glucose control and vascular outcomes in patients with type 2 diabetes. N Engl J Med., 2008; 358:25602572.

17. Baker CA and Manuelidis L. Unique inflammatory RNA profiles of microglia in Creutzfeldt-Jakob disease. Proc. Natl, Acad, Sci., 2003; 100:675-679.

18. Tang W, Lu, QY and Tian. "The growth factor progranulin binds to tnf receptors 
and is therapeutic against inflammatory

arthritis in mice," Science, 2011;

332(6028): 478-484. 